\title{
Attitudes toward Science Based on Analysis and Correlation: Learning Enjoyment \& Leisure Interest on Science
}

\author{
Tanti $^{1}$, Dwi Agus Kurniawan ${ }^{(2, *)}$, Nugroho Kurniawan ${ }^{3}$, Lika Anggraini ${ }^{4}$ \\ ${ }^{1}$ Faculty of Science and Technology, Universitas Islam Negeri Sultan Thaha Saifuddin, \\ Jambi, Indonesia \\ ${ }^{2,3,4}$ Faculty of Teaching and Education, Universitas Jambi, Jambi, Indonesia
}

\begin{abstract}
Received: November 02, 2019 This study aims to investigate attitudes towards science in secondary Revised: December 20, 2020 school students. The focus of research is to analyze and to correlate Accepted: December 21, 2020 attitudes towards IPA based on indicators of enjoyment and leisure interest in science learning. Method: This research was survey research. The results of the data came from a questionnaire. The sample consisted of 2815 Secondary School students in Muaro Jambi. Finding: The results showed positive results, based on the results of indicators: (1) enjoyment in science has a good category $(48.1 \%)$, (2) leisure interest in science has a moderate category $(47.2 \%)$ and this indicator leads to a positive trend supported by a positive attitude with a greater good $(38.4 \%$,$) while for the$ analysis of the correlation between the two indicators shows a positive $(0,000<0.05)$ and has a strong degree of correlation indicated by the value Pearson Correlation (0.716). Conclusion: it can be concluded that students' attitudes towards science based on analysis of indicators show positive attitudes and tend to be good, and based on correlation between the two attitude indicators also show positive results with strong correlation, furthermore concluded overall attitudes towards science at secondary school students in Muaro Jambi have a positive attitude and are categorized well.
\end{abstract}

Keywords: Science education, Character education, Attitudes toward science

(*) Corresponding Author: $\quad$ dwiagus.k@unja.ac.id

How to Cite: Tanti et al. (2021). Attitudes toward science based on analysis and correlation: Learning enjoyment \& leisure interest on science. Formatif: Jurnal Ilmiah Pendidikan MIPA, 11 (1): $113-126$. http://dx.doi.org/10.30998/formatif.v11i1.5142

\section{INTRODUCTION}

Investment in educational capital for humans is one essential and vital component for economic and social development of a country and education as a strategy to overcome poverty in most developing countries (Remi, 2018). Education is an integral part of all citizens. Horváthová and Čajková (2018), Education can be referred as the ability to use knowledge and experience. Therefore, most developed nations are doing every possibility and effort to ensure that their citizens have access to education (Chaka and Govender, 2017). Secondary education is the level of secondary school. In contrast to basic education, education in a secondary school subject has begun to be divided according to the discipline. One of them is the Science in secondary school that is an integration of the subject of Physics, Biology, and Chemistry.

Generally, Science learning in secondary school is taught by a Science teacher. Science teachers are responsible for teaching and learning activities and measuring students' attitudes. The attitude of students in secondary school towards Science is positive (Sakariyau, Taiwo, and Ajagbe, 2016). Through student's participation, Science teachers 
are ready to improve the teaching and learning of Science in the classroom and as a Leader of Science Teachers (STL) that facilitates professional learning in secondary schools (Pringle, Mesa, and Hayes, 2017). Science teachers have a central and crucial role to play in a shaping the future of Science education (Nezvalová and Svec, 2007). Classroom evaluation of Science teaching for each student can be measured from the evaluation of each student's attitude towards Science. The good assessment will also have a positive impact on Science education (Tinell, Asikainen, and Hirvonen, 2017). This attitude is very important because teachers may know each student's response to Science learning with an indication that students reject or accept Science in students.

Astalini, et. al. (2019b), Attitude is an expression or a response of students regarding learning. Attitudes have different perceptions, schooled the word 'attitude' is often used in the academic life of the students (Ali, Iqbal, and Saeed Akhtar, 2013). Each student has a different attitude towards Natural Science, depending on the factors that influence it, the difference can be viewed from the heterogeneous factors. Attitudes toward Science on individual is indicating all of feels and thinks regarding about Science (Sethi, 2015). Despite differences of opinion about attitudes, the manifestation of their attitude toward Science is important. Supported by Liaghatdar, Soltani, and Abedi (2011), "Attitudes toward science is important, because attitudes can enhance the educational achievements of the students and affect their performance".

Science is consisted by explaining natural and social phenomenon of students (Kang and Noh, 2017). Science learning provides a variety of experiences to understand scientific concepts and science processes (Oktalia, Wijayanti, and Ernawati, 2018). Students' attitudes toward Science subjects are seen from how their responses to Science subjects are either an interest in science or the difficulty of Science subjects. One of the goals of the Science learning is to cultivate students' positive attitudes towards science (Sofiani, Maulida, Fadhilah, and Sihite, 2017). Positive attitudes can be interpreted as attitudes that support students to learn, such as enjoying the lessons and negative attitudes are attitudes that inhibit students to learn. In measuring students' attitudes toward Science can be seen through three indicators, namely the adoption of an attitude of Science, fun in learning Science, and the interest of taking time in learning Science.

The enjoyment of learning is one a crucial factor in the process of student's education because happy behavior will determine the attitude of students towards the object. Enjoyment in learning is the emotional expression of students linked to student's motivation and willingness to learn at school (Manasia, 2015). The pleasure of learning in Science is the development of students' attitudes towards science that have a positive impact on students. Enjoyment of Science lessons toward Science is an expression of positive feelings about a situation that is done when studying science (Astalini a, et. al., 2019). The enjoyment or pleasure of learning Science can be defined as the student who has positive attitude in Science shown by students' feeling of comfort and pleasure to learn Science (Astalini b, et. al, 2019).

Leisure interest in Science is the student who has an interest to always spend time in activities in the field of Science. Bybee, McCrae, and Laurie (2009), Interest in Science is chosen because of its relationship and influence with achievement, class selection, career choice, and longlife learning. Narmadha and Chamundeswari (2013), learning from Science for these students is more effective, because of the interest developed in the subject. The learning experience of science is related to the interest and interest of students in studying Science, students who have high interest in Science will get a positive and significant result in Science learning. Bulunuz and Jarret (2010a), Students' background science experiences are described and in accordance with whether they have a low or high interest in Science. However, students often experience poor learning due to mistakes in 
the learning process either of the teaching methods used by the teacher to the difficulty of the delivery of the material. Therefore, as a science education professional, it is a must to determine an effective method for changing students' negative interest in Science to become a positive interest by helping them understand the Science (Jack and Lin, 2014a). Students who have an interest in spending time in Science are generally characterized by the efforts of students to continue to study and to apply scientific knowledge in everyday life even outside of the school's hours. Ainley and Ainley (2011), students with individual interests in Science will embrace opportunities to re-engage activities with science activities.

Based on the research findings, attitude is one of the important factors of the learning success. Especially in Science learning, students who have a positive attitude towards Science will have implications for the results of activities and learning outcomes of Science. Meanwhile, the negative attitude of students towards Science shows a decrease in the quality of learning. Developing attitudes towards Science is an integrated part of students with their learning activities. So that based on the findings and explanation of the theory above, it shows a positive impact on Science. This study discusses the analysis and the correlation between attitudes towards science in Science learning. These research questions are: 1) How are the student's attitudes based on the enjoyment learning in Science? 2) How are the students' attitudes based on career interest in Science? 3) How is the correlation of students' attitudes towards Science based on the indicators: learning enjoyment and leisure interest in Science?

Research focus are (1) to analyze student's attitudes toward Science based on indicatos: enjoyment in science \& leisure interest in science, then (2) to analyze the degree of correlation between the two students' indicators attitude toward Science. The purpose of the research is to identify how the attitude of secondary school students to Science object and how effective the two indicators are so as to improve student's attitudes in the secondary school in Jambi Province, Indonesia.

\section{METHOD}

The research used was survey research. Survey studies examine large and small populations by selecting and assessing selected samples from the population (Kerlinger, 2014). The subjects of the study were all seventh and eighth-grade students at junior level in Jambi Province, Indonesia. This research used the total sampling technique where the total number of junior students studied amounted to 2815 students consisting of 1255 male students and 1560 female students.

Data collection was carried out by giving research instrument in the form of the questionnaire "Attitudes toward Science". Dimensions of students' attitudes toward Science subjects are examined based on predetermined indicators, namely enjoyment in Science lessons and leisure interest in science. Students' attitudes toward Science subjects in the study were measured using the Likert scale. The scale of Likert scale strongly agrees (SA), agrees (A), not sure (NS), disagrees (D), and strongly disagrees (SD). Each positive item on the instrument has values: $\mathrm{SA}=5, \mathrm{~A}=4, \mathrm{NS}=3, \mathrm{D}=2$, and $\mathrm{SD}=1$. The score is reversed for negative items. This questionnaire data is given to students of State Secondary School in Muaro Jambi Regency, Jambi Province, Indonesia.

This research data was in the form of quantitative data in the analysis using descriptive statistics. Results from questionnaire data were processed using software or IBM SPSS Statistics. This treatment was aimed to see the attitude of Secondary School students toward Science in Muaro Jambi Regency, Jambi Province. 


\section{RESULTS AND DISCUSSION}

\section{Results}

The results of the study are derived from questionnaire of student's attitude towards Science. The questionnaire is used to measure students 'attitudes towards Science which amounts as many as 2815 students (as respondents), besides that in both questionnaire indicators will also be analyzed how the correlation degree of the indicators, this purpose is to strengthen data on students' attitudes towards Science. The measurement results use analysis: (1) descriptive statistics to analyze students' attitudes towards science based on indicators: enjoyment in Science \& leisure interest in Science, and (2) inferential statistics is aimed at analyzing how the relationship or correlation between both of the indicators. Both of these statistical analyses use IBM SPSS Statistics software. The results of this study are indicated by the tables and the statistics analysis below:

\section{a. Enjoyment in Science Lessons}

Table 1. is the result of descriptive analysis of student's attitudes toward Science based on the indicator of enjoyment in Science learning. Table 1 shows that students' attitudes towards Science in the indicator of enjoyment of Science lesson point out that the attitude of the dominant students are in the good category with a percentage of $48.1 \%$ (recorded 1354 students from 2815 students). So on this indicator, student's attitudes show a positive attitude. Then, on the table also shows the value of the standard deviation has a value which is smaller than the mean value, so that the result implies representation of all sample data and shows valid research data.

Table 1. Enjoyment in Science Lesson

\begin{tabular}{|c|c|c|c|c|c|c|c|}
\hline \multicolumn{3}{|c|}{ Classification } & \multirow{2}{*}{$\%$} & \multirow{2}{*}{$\begin{array}{l}\text { Standard } \\
\text { Deviation }\end{array}$} & \multirow{2}{*}{ Mean } & \multirow{2}{*}{ Modus } & \multirow{2}{*}{ Median } \\
\hline Interval & Attitude & Amount & & & & & \\
\hline $10,0-18,0$ & Very Bad & 8 & 0,3 & & & & \\
\hline $18,1-26,0$ & $\mathrm{Bad}$ & 106 & 3,8 & & & & \\
\hline $26,1-34,0$ & Enough & 835 & 29,7 & 0,78 & 3,8 & 4,0 & 4,0 \\
\hline $34,1-42,0$ & Good & 1354 & 48,1 & & & & \\
\hline $42,1-35,0$ & Very Good & 512 & 18,2 & & & & \\
\hline
\end{tabular}

\section{b. Leisure Interest in Science}

Table 2. is the result of the descriptive analysis of students' attitudes toward Science based on the indicator of leisure interest. Table 2, students' attitudes on indicators of leisure interest in Science show the dominant student's attitudes are in moderate category $(47,2 \%)$. However, when viewed from the results of table 2., student's attitude has a positive trend, as evidence from table 2, that the categories are: good $(38,4 \%)$ and very good $(6,9 \%)$, attitude categories are greater than the negative categories of students: very bad $(0,2 \%)$ and bad $(7,2 \%)$. 
Table 2. Leisure Interest in Science

\begin{tabular}{|c|c|c|c|c|c|c|c|}
\hline \multicolumn{3}{|c|}{ Classification } & \multirow{2}{*}{$\%$} & \multirow{2}{*}{$\begin{array}{l}\text { Standard } \\
\text { Deviation }\end{array}$} & \multirow{2}{*}{ Mean } & \multirow{2}{*}{ Modus } & \multirow{2}{*}{ Median } \\
\hline Interval & Attitude & Amount & & & & & \\
\hline $8,0-14,4$ & Very Bad & 7 & 0,2 & & & & \\
\hline $14,5-20,8$ & $\mathrm{Bad}$ & 203 & 7,2 & & & & \\
\hline $20,9-27,2$ & Enough & 1330 & 47,2 & 0,74 & 3,45 & 3,0 & 3,0 \\
\hline $27,3-33,6$ & Good & 1080 & 38,4 & & & & \\
\hline $33,7-40,0$ & Very Good & 195 & 6,9 & & & & \\
\hline
\end{tabular}

\section{Obstacles on Student's Attitudes towards Science}

Statistics on the results of measuring student's attitudes towards Science is carried out based on indicators: (1) enjoyment in Science lesson and (2) leisure interest in Science has shown good and positive results. However, there are still minor results, namely there are still negative attitudes. The result of the negative attitude is shown in the table 3 .

Table 3. Obstacles on Student's Attitude

\begin{tabular}{lll}
\hline Indicator & Obstacles (\%) & $\mathrm{N}$ \\
\hline Enjoyment in Science lesson & $4,2 \%$ & 114 \\
\hline Leisure Interest in Science & $7,4 \%$ & 210 \\
\hline
\end{tabular}

Table 3. Shows student constraints that are indicated by students' negative attitudes to Science. This constraints or obstacles are shown based on indicators: (1) enjoyment in Science lesson shows a negative attitude with a percentage of $4.2 \%$ (114 students) and (2) leisure interest in Science lesson with a percentage of 7.4\% (210 students). This percentage shows the magnitude of students' negative attitudes toward Science.

\section{Correlation: Enjoyment In Science Lesson and Leisure Interest In Science}

The attitude of students towards Science lessons can be shown based on these attitude indicators. The indicator will present the degree of relationship. In the results of the statistics, the table below shows the correlation of student's attitudes towards Science based on indicators: (1) enjoyment in Science lesson and (2) leisure interest in Science. This correlation measurement uses IBM SPSS Statistics software by analyzing the pearsson correlation. The results of the analysis provide results shown from 2 tables, namely: [1] table 4. Descriptive statistics and [2] table 5. Correlations.

Table 4. Descriptive Statistics

\begin{tabular}{lrrr}
\hline \multicolumn{4}{c}{ Descriptive Statistics } \\
\hline & Mean & Std. Deviation & $\mathrm{N}$ \\
\hline Enjoyment in Science & 36,944 & 5,87 & 2815 \\
& 2 & & \\
\hline Leisure Interest in Science & 27,986 & 4,52 & 2815 \\
& 1 & & \\
\hline
\end{tabular}


Table 4. shows descriptive statistic results on the indicators: (1) enjoyment in Science and (2) leisure interest in Science. Where the two indicators are used to see the degree of the relationship or correlation, and the results can provide conclusions related to student attitudes toward Science. The statistical results of the enjoyment in science lesson indicator show the std deviation (5.875) is smaller $(<)$ than the mean value (36.94), and the leisure interest indicator in Science shows the statistical results of the std value. Deviation (4.52) is smaller $(<)$ than the mean (27.98). The two indicators show the same results, i.e., the standard deviation value is smaller $(<)$ than the mean, thus concluding that the results represent the entire sample and show if the data is valid. Next, table 5. shows the correlation value of the two indicators.

Table 5. Corelation Statistics

\begin{tabular}{|c|c|c|c|}
\hline & & Enjoyment in Science & Leisure in Science \\
\hline \multirow{4}{*}{$\begin{array}{l}\text { Enjoyment in } \\
\text { Science } \\
\text { Lesson }\end{array}$} & Pearson & 1 &, $716^{* *}$ \\
\hline & Correlation & & \\
\hline & Sig. (2-tailed) & & ,000 \\
\hline & $\mathrm{N}$ & 2815 & 2815 \\
\hline \multirow{4}{*}{$\begin{array}{l}\text { Leisure } \\
\text { Interest in } \\
\text { Science }\end{array}$} & Pearson &, $716^{* *}$ & 1 \\
\hline & Correlation & & \\
\hline & Sig. (2-tailed) &, 000 & \\
\hline & $\mathrm{N}$ & 2815 & 2815 \\
\hline
\end{tabular}

The result of table 5 is a correlation between enjoyment in Science and leisure interest in Science. This correlation value comes from respondents of 2815 students. Based on the table shows the sig value: 0,000 (sig value $<0.05$ ), this value indicates that the indicators of enjoyment in science and indicators of leisure interest in science have a relationship. Besides that, the correlation between the two indicators also shows a positive correlation.

\section{Discussion}

Education is very important for humans that has an impact positively with the existence of education can change behavior and knowledge for the better (Astalini, et. al, 2019c). Basyah, Muslem, and Usman (2018) stated the issue of human resources, priorities should be given to efforts to prepare and to improve the skills and expertise of everyone to face the challenges and uncertainties of the future. Therefore, every individual is expected to have the ability to understand their surroundings, especially in the aspect of education. Education should be able to create a nation's regeneration, besides having knowledge skills, but also having character and skills (Napitupulu, Manalu, and Siahaan, 2019). In line with this, one of the development and application of important characters in education is the attitude of students. The results of this study aim to investigate students' attitudes towards Science. Eaton and Visser (2008), Attitudes have garnered an amount of scholarly attention across the social sciences.

Perception or misperception about Science provides a connection between attitudes and knowledge (scientific knowledge $\rightarrow$ perceptions about Science $\rightarrow$ attitudes toward Science) (Lee, 2018). So that reason is one of the underlying studies of students' attitudes towards science in this study. This research focuses on looking at students' attitudes towards Science. Students' attitudes towards Science will be shown by 2 indicators: (1) enjoyment in sciecne lesson, and (2) leisure interet in science, then strengthened by the degree of relationship/correlation between the two indicators. 


\section{a. Enjoyment in Science Lesson}

Describe as a result, the related educational, scientific, technological and innovation processes certainly play a central role (Arango-Botero, et. al, 2019). For this reason the learning process must be innovated, not only with traditional ways of learning, but educators should make the lesson more interesting and favored by students. Having fun or enjoy in learning, especially in the field of Science is a crucial factor. Students rated their 'enjoyment' on objects or activities with feelings or behaviors: hate it, dislike it, don't mind it, like, love it (Maharaj-Sharma and Sharma, 2017). Students assume that motivation behind their knowledge was simply interested and curious (Falk, Storkdieck, and Dierking, 2007). The conclusion is that the implementation of interest in happy learning in Science is very important. Based on the results of statistics table 1 show good results, this is indicated by the students' attitude of the dominant in the good category with a percentage of $48.1 \%$ or 1354 students. It means that the students' attitude on this indicator has a positive attitude. Supported from the results of interviews stating the results of positive attitudes from students towards Science.
$Q \quad$ : What do you think about Science? Do you like it?
A : In my opinion, Science lessons are complicated but exciting. Yes of course I'm happy with the lesson.
$Q \quad$ : Why do you like Science lessons?
A :Because based on learning experience related to Science, I will more easily understand the content of Science material by giving interest and comfort to the lessons.
$Q \quad$ :What positive impact you get it?
A :Applying to enjoy learning towards Science lessons can improve my Science learning outcomes at school?

The results of interviews conducted to students provide results that are directly proportional to the results of students' attitude statistics. Interviews show positive results, this is indicated by students' experience of Science that gets better results when they have a sense of pleasure and interest in learning Science. It means, conclusion if the positive attitude of students who are shown the pleasure of learning in Science will have a positive influence on their learning outcomes, while the negative attitude applies otherwise low achievement can be caused by a risk factor for the experience of enjoyment during learning (Hagenauer and Hascher, 2014). So that the results give the conclusion that students' attitudes towards science on this indicator have a positive role and need to be developed or implemented for students to create positive attitude towards students in Science. Based on fact, if students' attitudes are one of the key factors in learning Science (Liaghatdar, Soltani, and Abedi, 2011).

\section{b. Leisure Interest in Science}

Nasution (2019) stated that the teacher is one of the main assets and human resources in improving the quality of education. Therefore, educators have a role for students to provide fun and interesting educational learning, the purpose is that students have interest and passion to provide leisure time for learning. Leisure interest in Science makes more positive attitudes toward scientific inquiry and towards scientist for students (Holstermann, Grube, and Bogeholz, 2009). Interest in Science learning triggers and maintains the important affective component of Science and learning (Jack and Lin, 2018c). So it can be concluded that leisure has a significant influence on positive attitude. 
Furthermore, in table 3 the results of leisure interest in Science more in the category of quite well with the Mean 3.45 and Modus 3. From the results of Mean and Mode can be concluded that the attitude of students tends to be negative. This is supported also from the results of Table 2 which shows the number $47.2 \%$ or 1330 of the 2815 students are in the moderate category to fill with 1330 students. The high enough figure on the attitude of the students can be concluded as the negative attitude of the students. The high rate is also supported by the data of students who have a bad attitude and very bad with the amount of 7.4\%. This is supported by the results of the interview below:

$\begin{array}{ll}Q & : \text { What is your response if Science lessons are at school in multiply? } \\ A & : \text { I like Science, but I disagree, when the study time are added. } \\ Q & : \text { Do you often read the literature related Science at out side school? } \\ A & : \text { not really, but, usually I read book when I want it. }\end{array}$

From the results of the interview, students are reluctant to increase the hours of Science learning outside of school and the low interest of students in the surrounding Science activities. While the students who have the "not good" category is caused due to the factors of students who are not interested in reading books on Science articles. Students who have a good (positive) category of leisure interest in Science can be seen from students who still have an active interest in forming a discussion group about science after completion of school hours. The group work to train students to be patient and organized, to avoid frustration when conducting research, and to work independently (Ruiz-Mallen, et. al, 2016). From these results, it can be due to different students' interests amongst the other students. Jack and Lin (2017b), The task here is not to create interest, because it already exists in students. Furthermore, it is our duty to change new methods of teaching Science to foster a student's positive attitude toward interest in science.

\section{c. Obstacles on Students' Attitude}

The results of this study as a whole show a positive attitude towards Science. Although the results of the study in the majority showed a positive attitude, but there were still obstacles and minor students' outcomes, it was shown by the negative attitude of students. Students' constraints on students' attitudes are inferred from negative attitudes of students who have very bad categories and not good categories from statistical results (table 1-2). Students' negative attitudes toward Science assessed on: enjoyment in Science lesson, and leisure interest in Science.

The first obstacle in the enjoyment in Science indicator shows a percentage value of $4.2 \%$ or means that there are 114 students from 2815 students who have a negative attitude. So that the negative attitude in students in this indicator is interpreted by the feeling of students who are uncomfortable with learning Science. This makes students seem weak in mastering and implementing Science concepts. Piht and Eisenschmidt (2008) affirm that current student do not wish to study Science. The main factor of student displeasure in Science learning is based on student's learning experience. Enjoyment of Science lessons with related experience (Joyce and Farenga, 2010). Even students cannot apply them in solving relevant problems and particularly those which involve complex application of Science knowledge or tasks similar to real situations (Stefanova, Minevska, and Evtimova, 2010). It is observed that from some students, the students about the discourse of adding the allocation of Science learning in the classroom, and students do not like to wait for Science lessons during class time because students think that Science is less interesting and as a boring lesson. This factor causes low interest of students in Science learning. To 
increase students' Science interest, it needs to stimulate and to support the interest of students in these fields, to show their attractiveness and usefulness (Novák, Molnár, and Švrček, 2007).

Furthermore, the indicator of leisure interest in Science is the indicator with the highest percentage of obstacles that is $7.4 \%$ or 210 students behave negatively. This value shows how students are constrained on indicators of leisure interest in Science, first because students are not interested in reading books about Science articles or applying Science. Both students are unwilling to take the time to discuss with peers related to Science like doing simple experiments related to Science concept at home. Whereas students' interest in Science can be improved by linking classroom activities with the application of Science daily activities and peer discussions (Jocz, Zhai, and Tan, 2014). Essentially, it happens because students are not interested in Science activities outside of school hours. The cause is too often the instruction of Science interest and is separated from their daily experience (Kolodner, et. al, 2009).

\section{d. Correlation between Enjoyment in Science and Leisure Interest in Science}

This 21 st century can be called as the era of globalization, in this era the development of science, technology \& information is running very fast (Suardana, et. al, 2018). One of the most important goals of Science education is to teach students how to engage in scientific inquiry directly, it means that students should be able to integrate skills, knowledge, and attitudes to develop better concepts of scientific understanding (Zeidan and Jayosi, 2015). Science education is closely related to teaching practice, but also students' attitudes towards Science is a variable that has been positively associated with science achievement (Odom and Bell, 2015). Therefore, one of the objectives of this study is to see how the quality of students' attitudes toward Science, based on the degree of correlation between the two measured attitude indicators.

The correlation in this study is the analysis of indicators: [1] enjoyment in Science and [2] leisure interest in Science. Based on the statistical results in table 5. shows the positive correlation of the two indicators on the variable students' attitudes towards Science. This correlation is shown in table 5, which is the value of sig $=0,000$. The value of sig 0,000 is smaller than $0.05(0,000<0,05)$, so that it can be interpreted that there is a positive correlation on the enjoyment indicator in Science and leisure interest in Science. Positive correlation is interpreted by the relationship or correlation between these two indicators run into an increase that is directly proportional. So that the increase in the value of the enjoyment in Science indicator also applies equally to leisure interest in Science. This simple positive relationship means that when students have good behavior and attitudes on indicator [1], i.e., students are happy and are always motivated by learning Science, it will be directly proportional to indicator [2], i.e., students will also have an interest positive for always spending time regularly in learning or understanding Science concepts even if it is outside school hours. Therefore, researchers specifically consider educators to develop fun learning because it has a positive impact on students' attitudes. Supported by Bulunuz (2015b), Teachers' enjoyment of Science activities may also influence them to teach science in a playful manner.

Furthermore in table 5. also shows the degree of correlation shown in "Pearson Correlation". This degree of correlation illustrates how strong the relationship between two students' attitudes toward Science variables, namely: [1] enjoyment in Science lesson and [2] leisure interest in Science. Table 5. shows the Pearson correlation value is 0.716, based on the correlation coefficient $r$ correlation value: 0.716 on the 2 indicators of students' attitudes towards the Science shows a strong category. This strong category illustrates the 
level or quality of relationship between these two variables. So it can be interpreted that the strengthening of the enjoyment indicator in Science will also be followed by the strengthening of the leisure interest in Science indicators equally.

Based on the results of these correlations, it was concluded that students' attitudes to the indicators of enjoyment in Science and leisure interest in Science have a relationship indicated by a sig $=0,000$, and this value also shows a positive correlation between the two indicators. The positive correlation means that the two attitudinal indicators have a pattern of unidirectional increases, namely the positive trend of students derived from the indicator of enjoyment in Science lesson, then a positive trend in student's behavior will be followed by indicators of leisure interest in Science. Furthermore, based on the results of the degree of correlation (Pearson correlation) shows the value $=0.716$, this value gives the conclusion that the level of correlation or relationship between these indicators have a strong category. The strong category indicates a positive student's relationship on these two indicators. This means that the value of the strong category means that the degree of relationship between students in the indicators of enjoyment in Science lesson and leisure interest in Science have a close relationship with each other with good and positive quality. Supported by Kurniawan, et. al. (2019) Science and character in education become an important focus in the effectiveness and the succes of learning. Therefore, the researchers conclude based on the results of students' attitudes character towards Science show a positive attitude towards Science.

\section{CONCLUSION}

Results of descriptive statistics on students' attitudes toward Science on indicators; enjoyment in Science and leisure interest in Science show good and positive results. This is evidenced from the dominant values in the attitude categories on both indicators, where indicators [1] enjoyment in Sciecne is categorized good and [2] leisure interest in Science is categorized quite well with positive trends. Supported also from the results of indicator correlations: [1] enjoyment in Science lesson and [2] leisure interest in Science show a positive correlation and have a strong degree of relationship. Therefore, it can be concluded from these results, the attitude of students has a positive attitude and good behavior towards Science. Thus, these results can imply that every student who has a positive attitude towards Science will have a positive effect on the activities and learning outcomes of Science, and based on the results of the correlation of attitudes towards Science in students show a positive attitude with a strong correlation $(0,716)$, it means that students who enjoy of learning Science will be in line with students' leisure interest in spending time of Science, which means that between enjoyment in Science and leisure interest in Science will show mutual support in Science learning activities.

\section{ACKNOWLEDGEMENTS}

Sincerely, Thank you for the implementation of this research and this article we convey to: (1) Headmaster of State Secondary School in Jambi province, (2) Department of Physics Education, Jambi University, (3) All participants and volunteers involved in this research. 


\section{REFERENCES}

Ainley, M. \& Ainley, J. (2011). Student engagement with science in early adolescence: The contribution of enjoyment to students' continuing interest in learning about science. Contemporary Educational Psychology, 36(1), 4-12. https://doi.org/10.1016/j.cedpsych.2010.08.001

Ali, M. S., Iqbal, A., \& Saeed Akhtar, M. M. (2013). Students' attitude towards science and its relationship with achievement score at intermediate level. Journal of Elementary Education, 25(2), 61-72.

Arango-Botero D., Chalela S., Valencia-Arias A. (2019). Development and validation of a scale to measure the motivation to pursue a graduate course. Integration of Education, 23(2), 196-207. DOI: 10.15507/1991-9468.095.023.201902.196-207

Astalini, Darmaji, Kurniawan, D. A. \& Destianti, A. (2019). Description of the dimensions attitudes towards science in junior high school at muaro jambi. International Journal of Sciences: Basic and Applied Research (IJSBA),) 47(1), 1-11. http://gssrr.org/index.php?journal=JournalOfBasicAndApplied

Astalini, A., Kurniawan, D. A., Kurniawan, N., \& Anggraini, L. (2019). Evaluation of student's attitude toward science in Indonesia. Open Jounal for Educational Research, 3(1), 1-12.https://doi.org/10.32591/coas.ojer.0301.01001a

Astalini, Kurniawan, D. A., Perdana, R. \& Kurniawan, W. (2019). identification attitudes of learners on physics education. Journal of Educational and Technology, 5(1) 3948. https://doi.org/10.26858/est.v5i1.8231

Basyah, N. A., Muslem, A. \& Usman, B. (2018) The Effectiveness of using the jigsaw model o improve students' economics teachin-learning achievement. The New Educational Review, 51(1): 31-40. DOI: 10.15804/tner.2018.51.1.02

Bulunuz, M., \& Jarret, O. S. (2010). Developing an interest in science: background experience of preservice elementary teachers. International Journal of Environmental \& Science Education, 5(1), 65-84.

Bulunuz, M. (2015). The role of playful science in developing positive attitudes toward teaching science in a science teacher preparation program. Eurasian Journal of Educational Research, 58, 67-88. http://dx.doi.org/10.14689/ejer.2014.58.2

Bybee, R., McCrae, B., \& Laurie, R. (2009). PISA 2006: An Assessment of scientific literacy. Journal of Research in Science Teaching, 46(8), 865-883. DOI $10.1002 /$ tea. 20333

Chaka, J. G. \& Govender, I. (2017). Student' perceptions and readiness toward mobile learning college of educationn: a nigeria perspective. South African of Journal Education. 37(1), 1-12. doi: 10.15700/saje.v37n1a1282

Eaton, A. A., \& Visser, P. S. (2008). Attitude importance: understanding the causes and consequences of passionately held views. Social and Personality Psychology Compass, 2/4 (2008), 1719-1736. DOI: 10.1111/j.1751-9004.2008.00125.x

Falk, J. H., Storkdieck, M., \& Dierking, L. D. (2007). Investigating public science interest and understanding: evidence for the importance of free-choice learning. Public Understanding of Science, 455-469.

Hagenauer, G. \& Hascher, T. (2014). Early adolescents' enjoyment in learning situations at school and its relation to student achievement. Journal of Education and Training Studies, 2(2), 20-30. http://dx.doi.org/10.11114/jets.v2i2.254

Horváthová Z., Čajková A. Social and economic aspects of the EU's Education Policy. Integration of Education, 22(3), 412-425. DOI: 10.15507/19919468.092.022.201803.412-425 
Jack, B. M., \& Lin, H.-S. (2014). Igniting and sustaining interest among students who have grown cold toward science. Science Education, 98(5), 792-814. https://doi.org/10.1002/sce.21119

Jack, B. M., \& Lin, H.-s. (2017). Making learning interesting and its application to the science classroom. Studies in Science Education, 53(2), 1-29. https://doi.org/10.1080/03057267.2017.1305543

Jack, B. M., \& Lin, H.-s. (2018). Warning! Increases in interest without enjoyment may not be trend predictive of genuine interest in learning science. International Journal of Educational Development, 62(2018), 136-147. https://doi.org/10.1016/j.ijedudev.2018.03.005

Jocz, J. A., Zai, J. \& Tan, A. L. (2014) Inquiry learning in the singaporean context: faktor affecting student interest in school science. International Journal Of Science Education, 36(15), 2596-2618. https://doi.org/10.1080/09500693.2014.908327

Joyce, B. A., \& Farenga, S. J. (2010). Informal science experience, attitudes, future interest in science, and gender of high-ability students: an exploratory study. School Science and Mathematic, 431-437.

Kang, Houn Tae \& Noh, Suk Goo. (2017). The Effect on elementary science education based on student's pre-inquiry. Universal Journal of Educational Research, 5(9), 1510-1518. DOI: 10.13189/ujer.2017.050908

Kerlinger, F. N. (2014). Asas-Asas Penelitian Behavioral. Yogyakarta: Gadjah Mada University Press.

Kurniawan, D. A., Astalini, A., Kurniawan, N. \& Pathoni, H. (2019). Analisis korelasi sikap siswa dan disiplin siswa terhadap IPA pada siswa SMP di Propinsi Jambi. Jurnal Pendidikan Fisika dan Keilmuan (JPFK), 5(2), 59-71. Doi: http://dx.doi.org/10.25273/jpfk.v5i2.5014

Lee, S., \& Kim, S.-H. (2018). Scientific knowledge and attitudes toward science in south korea: does knowledge lead to favorable attitudes. Science Communication SAGE Journal, 1-26. https://doi.org/10.1177\%2F1075547017753189

Liaghatdar, M. J., Soltani, A., \& Abedi, A. (2011). A Validity study of attitudes toward science scale among iranian secondary school students. International Education Studies, 4(4), 36-46. http://dx.doi.org/10.5539/ies.v4n4p36

Maharaj-Sharma, R., \& Sharma, A. (2017). Using ICT secondary school science teaching - what students and teachers in Trinidad and Tobago say? European Journal of Education Studies, 2501-1111.

Manasia, L. (2015). Enjoyment of learning in upper secondary education. An exploratory Research. Social and Behavioral Sciences 1, 639-646.

Napitupulu, S., Manalu, D. B. \& Siahaan, S. (2019). Scientific Approach-Based English Learning Strategy (SABELS). The New Educational Review, 56(2), 41-52. DOI: 10.15804/tner.2019.56.2.03

Narmadha, U., \& Chamundeswari, D. (2013). Attitude toward learning of science and academic achievement in science among students at the secondary level. Journal of Sociological Research, 4(2), 114.

Nasution, N. (2018). The effect of incentive reward, school principal leadership, work motivation on the perfomance of senior high school teachers in Medan. The New Educational Review, 53(3), 62-70. DOI: 10.15804/tner.2018.53.3.05

Nezvalová, D., \& Svec, M. (2007). Some trends in science teacher training: the experience in The United States and The Czech Republic. Problems of Education in the 21st Century, 1(2007), 85-94.

Novák, B., Molnár, J., \& Švrček, J. (2007). Mathematics for the talented ones as well as the others. Problems of Education in the 21st Century, 59-66. 
Odom, A. L. \& Bell, C. V. (2015). Associations of middle school student science achievement and attitudes about science with student-reported frequency of teacher lecture demonstrations and student-centered learning. International Journal of Environmental \& Science Education, 10(1), 87-97. doi: 10.12973/ijese.2015.232a

Oktalia, R., Wijayanti, A., \& Ernawati, T. (2018). Everyone is a teacher here effect on science learning achievement based on critical thinking skills. Formatif: Jurnal $\begin{array}{llll}\text { Ilmiah Pendidikan } & \text { MIPA, } & 8 & \text { (3), }\end{array}$ http://dx.doi.org/10.30998/formatif.v8i3.2797

Piht, S., \& Eisenschmidt, E. (2008). PUPILS' attitudes toward mathematics: comparative research between Estonian and finnish practice Schools. Problems of Education in the 21 st Century, 97-106.

Pringle, P. M., Mesa, J., \& Hayes, L. (2017). Professional development for middle school?. Journal of Science Teacher Education, 57-72.

Remi S.S., Kharisma B (2018). Impact of economic situation on availability of secondary education in Indonesia. Integration of Education, 22(4), 596-611. DOI: 10.15507/1991- 9468.093.022.201804.596-611

Ruiz-Mallén, I., Riboli-Sasco, L., Ribrault, C., Heras, M., Laguna, D., \& Perié, L. (2016). Citizen Science: toward transformative learning. Science Communication, 523534.

Sakariyau, A. O., Taiwo, M. O., \& Ajagbe, O. W. (2016). An investigation on secondary school students' attitude towards science in Ogun State, Nigeria. Journal of Education and Practice.

Sethi, U. (2015). Study of attitude of the students towards science in relation to certain nonschool factors. International Journal of Education and Information Studies, 75-80.

Sofiani, D., Maulida, A. S., Fadhilah, N., \& Sihite, D. Y. (2017). Gender differences in students' attitude toward science. International Conference on Mathematic and Science Education. 895). IOP Publishing.

Stefanova, Y., Minevska, M., \& Evtimova, S. (2010). Scientific literacy: problems of science education in bulgarian school. Problems of Education in the 21st Century, 113-118.

Suardana, I N., Redhana, I W., Sudiatmika, A. A. I. A. R., \& Selamat, I N. (2018). Students' critical thinking skills in chemistry learning using local culture-based 7E Learning Cycle Model. International Journal of Instruction, 11(2), 399-412. https://doi.org/10.12973/iji.2018.11227a

Tinell, R., Asikainen, M. A., \& Hirvonen, P. E. (2017). Learning assessment views and perceptions of finnish teachers and international students in postgraduate physics studies. Problems of Education in the 21st Century, 270-287.

Zeidan, A. H. \& Jayosi, M. R. (2014). Science process skills and attitudes toward science among Palestinian secondary school students. World Journal of Education, 5(2), 13-25. http://dx.doi.org/10.5430/wje.v5n1p13 
Tanti et al. / Formatif: Jurnal Ilmiah Pendidikan MIPA 11(1), 113-126

This page intentionaly left blank 